\title{
DIS3 wt Allele
}

National Cancer Institute

\section{Source}

National Cancer Institute. DIS3 wt Allele. NCI Thesaurus. Code C96359.

Human DIS3 wild-type allele is located in the vicinity of $13 q 22.1$ and is approximately 27 $\mathrm{kb}$ in length. This allele, which encodes exosome complex exonuclease RRP44 protein, plays a role in the modulation of ribosomal RNA processing. 